\title{
PERAN PEMERINTAH DESA DALAM PENGELOLAAN BUMDES DI DESA SINDANGKASIH
}

\author{
Murniati, La ode Abdul Harlan \\ Department of Government Studies, Faculty of Social and Political Sciences, \\ Universitas Muhammadiyah Kendari, email: murniati@umkendari.ac.id \\ Department of Government Studies, Faculty of Social and Political Sciences, \\ Universitas Muhammadiyah Kendari, email: laodeharlan@umkendari.ac.id \\ Department of Government Studies, Faculty of Social and Political Sciences, \\ Universitas Muhammadiyah Kendari
}

\begin{abstract}
Abstrak
Badan Usaha Milik Desa (BUMDes) merupakan program pemerintah desa yang harus dikelola dengan baik dalam rangka meningkatkan ekonomi masyarakat. Tujuan penelitian ini adalah untuk mengetahui Peran Pemerintah Desa dalam pengelolaan BUMDes. Penelitian yang dilakukan merupakan penelitian deskriptif kualitatif. Tehnik pengumpulan data menggunakan wawancara, observasi dan dokumentasi. Tahapan dalam penelitian ini adalah menentukan lokasi penelitian, pengumpulan data dan menganalisis data, laporan akhir. Hasil penelitian menunjukkan bahwa Pengelolaan Badan Usaha Milik Desa (BUMDes) yang telah dilaksanakan dengan baik dari segi peran pemerintah desa, namun dalam pengelolaannya masih kurang anggaran yang diberikan untuk bantuan simpan pinjam dan masih dibatasi untuk warga yang sudah memiliki usaha serta untuk memproduksi sarana pertanian (sarprodi) masih terbatas. BUMDes juga masih belum bisa menjangkau keseluruhan masyarakat. Masih banyaknya masyarakat yang menjual hasil panennya langsung ke pasar atau ke perusahaan lain karena BUMDes belum mampu untuk menampung semua hasil panen dari masyarakat desa.
\end{abstract}

Kata kunci: BUMDes, Desa Sindangkasih Peran Pemerintah Desa, Tata Kelola BUMDes.

\section{PENDAHULUAN}

Desa merupakan organisasi pemeritahan terkecil (Anggaeni, Maria, 2016), terbawah, terdepan dan terdekat dengan masyarakat (Suprojo, 2019). Pendirian BUMDes berdasarkan UU No. 23 tahun 2014 tentang Pemerintahan Daerah, UU No. 6 tahun 2014 tentang Desa dalam Pasal 87 ayat (1) yang berbunyi, "Desa dapat mendirikan Badan Usaha Milik Desa yang disebut BUMDes," dan ayat (2) yang berbunyi, "BUMDesa dikelola dengan semangat kekeluargaan dan kegotongroyongan," dan ayat (3) yang berbunyi, "BUMDesa dapat menjalankan usaha di bidang ekonomi dan atau 
pelayanan umum sesuai dengan ketentuan peraturan perundang-undangan, serta PP No. 72 tahun 2005 tentang Desa. Dalam UU No. 23 tahun 2014 tentang Pemerintahan Daerah pada Pasal 213 ayat (1) disebutkan bahwa, "Desa dapat mendirikan badan usaha milik desa sesuai dengan kebutuhan dan potensi desa". Dalam pasal 1 angka 4 Peraturan Menteri dalam Negeri Nomor 39 tahun 2010 tentang Badan Usaha Milik Desa, BUMDes diartikan sebagaimana yang berbunyi: Badan Usaha Milik Desa, yang selanjutnya disebut BUMDes, adalah usaha desa yang dibentuk/ didirikan oleh pemerintah desa yang kepemilikan modal dan pengelolaannya dilakukan oleh pemerintah desa dan masyarakat.

BUMdes merupakan salah satu alternatif dalam meningkatkan perekonomian di pedesaan (Samsir, 2016). (Dewi, Amelia, 2014), (Zulkarnain Ridlwan, 2014). Ada filosofi yang melatar belakangi terbentuknya BUMDEs. BUMDes tidak semata untuk mencari keutungan namun untuk pelayanan masyarakat, kedua, sebagai aktivitas nilai tambah ekonomi bagi warga desa, ketiga, sebagai social enterprise (Titioka, 2020).

Kabupaten Konawe Selatan terdiri dari 25 kecamatan, 15 kelurahan dan 336 desa. Di Kabupaten Konawe Selatan, sudah terdapat 200 desa yang memiliki BUMDes dari target 336. Dari 200 Bumdes yang terbentuk di masing-masing desa tercatat 20 Bumdes dinyatakan mandiri dalam menjalankan usaha dan piawai mengelola pendapatan, sedangkan sisanya masih dalam tahap awal dan pengembangan termasuk BUMDes Desa Sindangkasih yang terbentuk berdasarkan Peraturan Desa Sindangkasih Nomor 04 Tahun 2016.

Pengelolaan BUMDes Di Desa Sindangkasih belum di kelolah dengan baik karena adanya indikasi dana desa yang tidak transparan, di mana pembangunan di desa yag menggunakan dana desa, banyak yang tidak tepat sasaran,dan tidak di ketahui penggunaanya. Hal ini menyebabkan adanya ketidak percayaan masyarakat kepada pemerintah desa. tak hanya itu, pembelian hewan ternak dari dana desa yang di kelolah oleh BUMDes tidak di ketahui masyarakat, dan yang mendapatkan bantuan tersebut hanya keluarga dari aparat desa saja, serta pengelolaan BUMDes yang tak transparan kepada masyarkat desa sindang kasih.

Berdasarkan hal tersebut ini maka penulis tertarik untuk mengadakan penelitian tentang Peran Pemerintah Desa dalam pengelolaan BUMDes Di Desa Sindangkasih Kecamatan Ranometo Barat Kabupaten Konawe Selatan.

\section{METODE PENELITIAN}

Metode penelitian yang peneliti gunakan adalah tehnik deskriptif kualitatif dengan teknik pengumpulan data terdiri dari. Menurut (Miles Matthew B, 2007) mengemukakan bahwa analisis terdiri dari tiga alur kegiatan yang terjadi secara bersamaan yaitu: reduksi data, penyajian data, penarikan kesimpulan/verifikasi. Adapun metode dalam pengumpulan data dalam penelitian ini adalah:

- Wawancara berupa metode pengumpulan data dengan cara tanya jawab sepihak yang dikerjakan secara sistematis dan berlandaskan pada tujuan penyelidikan. Pada proses tanya jawab itu masing - masing pihak dapat 
menggunakan saluran - saluran komunikasi secara wajar dan lancar. Oleh karena itu wawancara dilakukan dengan menggunakan pedoman wawancara yang bersifat semi struktur artinya wawancara dengan kombinasi antar pedoman wawancara yang telah disiapkan dan tergantung pada proses jalannya wawancara itu sendiri. Adapun proses wawancara itu memfokuskan tentang peran pemerintah desa dan pengelolaan BUMDes.

- Observasi merupakan metode pengumpulan data esensial dalam penelitian, apalagi penelitian dengan pendekatan kualitatif. Agar memberikan data yang akurat dan bermanfaat, observasi sebagai metode ilmiah harus dilakukan oleh peneliti yang sudah melewati latihan-latihan yang memadai, serta telah mengadakan persiapan yang teliti dan lengkap.

- Dokumentasi sebagai sumber data lainnya yang sifatnya melengkapi data utama dan bersifat relevan dengan masalah dan fokus penelitian.

Dalam penelitian ini digunakan analisis data deskriptif kualitatif dengan langkah

- langkah model analisis interaktif (interactive mode of analisis) seperti yang

dikembangkan oleh Miles dan Huberman

\section{Hasil Penelitian dan Diskusi}

\section{Hasil Penelitian Tentang Peran Pemerintah Desa}

Meskipun BUMDes terpisah dari struktur formal pemerintahan Desa, BUMDes tidak berdiri sendiri secara eksklusif. kebijakan pendirian BUMDES harus melalui peraturan Desa. Yang disiapkan oleh kepala Desa bersama BPD dan tokoh masyarakat. karena itu dalam konteks ini pemerintah desa dan BPD berwenang melakukan pengawasan umum terhadap BUMDES untuk menjaga agar BUMDes berjalan.

Peran pemerintah Desa dalam mengelola BUMDes yaitu mendirikan, berpartisipasi dalam mengendalikan program kerja yang diselenggarakan BUMDes untuk pengembangan dan pemberdayaan masyarakat di desa seperti pemberian pinjaman modal usaha. Keterlibatan perangkat desa dalam pengelolaan BUMDes adalah adanya pengawasan, pengontrolan dan evaluasi dari program BUMDes. Perangkat Desa menjalankan tugas, fungsi, wewenang dan tanggung jawab untuk mengurus dan menjalankan kehendak masyarakat terutama dalam mengembangkan BUMDes.

Dalam penelitian peran pemerintah desa terdiri dari 3 indikator yang akan di kaji yakni :

\section{- Peran Pemerintah Desa Sebagai Fasilitator}

Fasilitator adalah menciptakan kondisi yang kondusif bagi pelaksanaan pembangunan untuk menjembatani berbagai kepentingan masyarakat desa (Suprojo, 2019). Sebagai fasilitator, pemerintah memberi pendampingan melalui pelatihan, pendidikan, dan peningkatan keterampilan, memberi modal usaha kepada masyarakat. (Sujarweni, 2019). Dengan adanya bantuan modal dana BUMDes ini akan meningkatkan pengolahan potensi desa sesuai dengan kebutuhan masyarakat dan pendampingan dalam pengembangan BUMDes.

Berdasarkan hasil wawancara dengan bapak Kepala Desa Sindangkasih, beliau mengemukakan bahwa: 
“ Kami selaku pemerintah desa memberikan pemahaman terlebih dahulu apa manfaat bumdes kepada masyarakat selanjutnya memberikan pemahaman kepada masyarakat bahwa pentingnya bumdes dalam mensejahterahkan masyarakat. Olehnya karena itu, saat ini kami memfasilitas bumdes dalam memberikan dana sebagai modal usaha kepada masyakat dan mereka sangat antusias. Modal yang kami berkan kepada bumdes tahun 2021 sebanyak 40 juta rupiah, selain itu kami juga memberikan pelatihan keterampilan bagi warga seperti keterampilan menjahit lalu kami belikan mesin jahit sebagai modal awal " (Ahmad Supena, S.Ip, 28 Maret 2021).

Wawancara selanjutnya dari salah seorang warga yang benama Asep Rahmat mengemukakan bahwa:

"Peran pemerintah desa sebagai fasilitator menurut saya berjalan dengan baik apalagi Bumdes ini diketahui sudah lama berdiri sehingga masyarakat yang memiliki aktifitas sebagai petani sama-sama membicarakan secara serius didalam musyawarah tahunan tentang bidang usaha bumdes. Salah satu usaha bumdes yang kami rasakan membantu adalah penyediaan pakan ternak" (wawancara dengan Asep Rahmat, 28 Maret 2021)

Hasil wawancara diatas juga didukung hasil wawancara oleh salah satu warga masyarakat yang memberikan pernyataan bahwa:

"Dijelaskan bahwa Jenis usaha yang bisa di beri bantuan dana modal dari BUMDes adalah warga masyarakat yang mempunyai usaha seperti pedagang- pedagang, yang mempunyai usaha toko, kios, penjual sayur maupun usaha- usaha lainnya serta kegiatan-kegiatan lokal yang ada di desa itu sendiri".

Berdasarkan hasil wawancara diatas, diperoleh kesimpulan bahwa pemerintah desa setempat cukup berperan sebagai fasilitator dalam pengembangan BUMDes yang dibuktikan dengan memberikan bantuan berupa dana untuk memfasilitasi masyarakat dalam mengembangkan usahanya, untuk dikelola secara bersama bagi pengelola BUMDes, jadi masyarakat yang mempunyai/memiliki usaha ternak ayam merasa senang karena mereka merasa terbantu dengan adanya bantuan dana serta penyediaan pakan ternak yang sudah disiapkan di BUMDes setempat.

\section{- Peran Pemerintah Desa sebagai Mediator}

Berdasarkan hasil wawancara dengan Kepala Desa Sindangkasih, beliau menyatakan bahwa:

“ Pada dasarnya yang kami lakukan lebih pada komunikasi langsung kepada masyarakat, petani, peternak serta bumdes. Alhumdulillah sampai saat ini belum ada masalah yang dapat merugikan kepentingan masyarakat. Olehnya itu kami mengharapkan kepada pengurus baru bumdes lebih kreatif dalam mewujudkan pemberdayaan masyarakat, pengurus bumdes pada periode ini masih anak muda, dalam tiga bulan kepengurusan mereka sudah melakukan terobosan untuk pengembangan usaha bumdes. Salah satu usaha yg berkembang yaitu jenis usaha penyediaaan pakan ternak ayam petelur. (usaha Saprodi).

Hasil wawancara di atas didukung pula oleh ketua pengelola BUMDes, beliau mengemukan bahwa: 
"Untuk saat ini bentuk mediasi yang dilakukan pemerintah masih sebatas sosialisasi terbuka kepada masyarakat dan bahkan kepada petani serta peternak, menurut kami hal itu sudah sangat membantu dan bahkan usaha safrodi yang ada di kios bumdes disambut dengan baik serta adanya pertemuan intens antara bumdes dengan peternak ayam petelur. Hal tersebut penting dikarenakan bumdes bisa dipercayakan untuk mengelolah hasil ternak untuk di jual ke konsumen (Darmansyah, S.P., M.P)

Dari dua hasil wawancara di atas juga sesuai dengan hasil wawancara peneliti dengan salah satu tokoh masyarakat yang juga merupakan anggota BUMDes:

"Mediasi yang dilakukan pemerintah baik kepada masyarakat maupun pelaku usaha biasanya di musyawarah umum, dimusyawarah ini di bahas juga tentang jenis" usaha bumdes ada pun dalam dalam bentuk pertemuan secara khusus dengan pelaku usaha pemerintah dan bumdes belum pernah dilaksanakan (Endang S.IP)

\section{- Peran Pemerintah Desa sebagai Pengawas}

Wawancara dengan kepala desa mengemukakan bahwa

“ Pengawasan yang kami lakukan lebih pada pengawasan langsung, baik menanyakan kepada masyarakat maupun kepada pengurus bumdes, keaadaan sekarang belum ada kendala yang signifikan bahkan kami selaku pemerintah masih perlu menambahkan modal usaha bumdes agar lebih cepat berkembang".

Selanjutnya wawancara dengan bapak Darmansyah, SP, MP (Ketua Bumdes) umur 26 tahun: "Bentuk pengawasan pemerintah desa kepada kami secara terus menerus memantau kios bumdes dan memantau kandang peternak secara langsung. Hal itu bisa jadi dilakukan oleh pemerintah desa dalam hal ini kepala desa langsung sebagai bentuk pengawasan kepada kami"

Wawancara selanjutnya Bapak Endang S.IP Tokoh Masyarakat: "pengawasan yang dilakukan oleh pemerintah desa terhadap bumdes biasanya kepala desa maupun aparat desa terkadang mengunjungi pelaku usaha dan menanyakan juga kepada kami tentang bumdes"

Dari keseluruhan informasi yang kami peroleh baik melalui informan maupun hasil pengamatan kami di lapangan diperoleh bahwa secara umum pemerintah desa dalam hal ini kepala desa cukup berperan dalam pengelolaan BUMDes.

\section{Pengelolaan BUMDes}

\section{- Kooperatif.}

Bumdes dalam pelaksanaan dan kepemilikan modal dikelola oleh pemerintaha desa dan masyarakat. (Agunanto, 2016).

Berdasarkan hasil wawancara dengan bapak Kepala Desa Sindangkasih, beliau mengemukakan bahwa:

“Dengan adanya pengurus bumdes yang masih muda maka kami percaya pengurus bumdes akan lebih kreatif dalam mengelola usaha dan juga kami selaku pemerintah lebih koperatif dalam memahmi kreatifitas bumdes. Olehnya itu intensitas kami kepada petani maupun pelaku usaha lainnya terus menerus kami lakukan sosialisasi tentang usaha kios bumdes" 
Wawancara serupa juga dikemukakan oleh Ketua BUMDes, berikut pernyataanya:

"Pemerintah desa sangat koperatif dalam melakukan sosialisasi, pengawasan bahkan mengajak masyarakat untuk selalu memberikan masukan kepada pemerintah dan bumdes" (Darmansyah).

Berdasarkan hasil wawancara di atas, diketahui bahwa pengelola BUMDES Desa Sindangkasih saling berkerja sama dengan baik, kompak serta diharapkan pengelolahnya lebih kreatif dalam mengelolah usaha BUMDes. koperatif serta mengajak masyarakat untuk selalu memberikan masukan ataupun ide-ide kepada pemerintah desa maupun pada para pengelolah BUMDes untuk menciptakan BUMDes yang lebih maju dalam hal usaha maupun keuntungan yang diperoleh.

\section{- Partisipatif}

Hasil wawancara dengan Bapak Asep Rahmat, umur 51, Pendidikan terakhir S1:

"Partisipasi kami sebagai masyarakat pertama ikut serta dalam pembahahasan musyawarah tahunan dan mendukung BUMDes dalam mengelola usaha untuk kebutuhan masyarakat maupun petani dan peternak misal bentuk partisipasi kami yaitu kebutuhan ternak kami apabila ada di kios Bumdes maka kami beli di bumdes dan kalo tidak ada di bumdes baru kami beli di kota Kendari. Olehnya itu kami memberikan masukan kepada bumdes dan pemerintah desa agar kebutuhan-kebutuhan kami dapat disediakan di kios bumdes".

Wawancara diatas juga didukung oleh bapak Muhammad Anwar Fadlil umur 30 pendidikan terakhir S1: "Pengurus bumdes tidak kaku menyempaikan usahanya kepada masyarakat sehingga kami masyarakat dan juga pelaku usaha secara langsung berpartisipasi dan juga mendukung bumdes untuk berkembang".

Dari hasil wawancara di atas terlihat dari segi partisipatif BUMDES terhadap masyarakat desa itu sangat baik dan hal itulah yang membuat masyarakat puas dengan pelayanan yang BUMDes berikan kepada masyarakat Desa Sindangkasih.

\section{- Transparansi}

Wawancara Darmansyah, SP, MP (Ketua Bumdes) umur 26 tahun:

"Untuk saat ini bentuk transparansi masih kepemerintah desa dalam laporan harian, namun laporan tersebut belum tertulis, Insya Allah kami akan laporkan hasil usaha kami secara tertulis di forum desa baik laporan triwulan maupun laporan tahunan".

Wawancara selanjutnya dari bapak Muhammad Anwar Fadlil umur 30 pendidikan terakhir S1: sepengetahuan saya untuk transparansi yang kami ketahui usaha kios bumdes samakin banyak ketersediaannya walaupun kami tidak mengetahui berapa penghasilan bumdes perbulan".

Wawancara Kepala Desa: transparansi bumdes dalam mengelola usaha sangat penting. Untuk kepengrusan yang baru ini selama 3 bulan berjalan 
belum ada rapat untuk pelaporan usaha bumdes, namun intensitas pertemuan kepada kami selaku pemerintah hampir setiap hari dalam melakukan diskusi maupun strategi bumdes dalam mengelola usaha ke depan.

Berdasarkan ketiga hasil wawancara diatas disimpulkan bahwa dalam hal transparansi pengelolah BUMdes belum maksimal, ini disebabkan karena pembentukan kepengurusan BUMDes yang baru berjalan kurang lebih tiga(3) bulan, jadi untuk pelaporan secara tertulis belum ada baru sebatas penyampiaan harian ke kepala desa sedangkan laporan ke masyarakat belum karena masih menuggu waktu pelaksanaan forum desa dan Rapat Anggaran Tahunan. Kedepan diperlukan rencana-rencana pembangunan desa (Suhu, 2020)

\section{- Akuntable}

Wawancara dengan bapak Muhammad Anwar Fadlil umur 30 pendidikan terakhir S1:

“Untuk pertanggungjawaban secara internal kami tidak mengetahuinya jadi yang kami tau pada saat musyawarah tahunan, untuk pengrus baru ini setau saya belum ada pertanggungjawaban dikarenakan pengurus bumdes baru berjalan 3 bulan.

Selanjutnya wawancara dengan Sekretaris Desa:

"Pertanggungjawaban bumdes setiap tahun di Rapat Anggaran Tahunan untuk pertanggungjawaban tiap 3 bulan dilakukan secara internal di Bumdes".

Kesimpulan dari hasil wawancara mengenai akuntable diatas menunjukkan bahwa selama periode kepengurusam BUMDes saat ini di Desa Sindang Kasih belum ada pertanggungjawaban resmi yang tertulis karena belum pernah diadakan rapat forum desa maupun rapat anggaran tahunan.

\section{- Sustainable}

Wawancara Kepala Desa: "Sangat penting memikirkan keberlanjutan usaha bumdes kedepan. Bahkan kami memhami bahwa jika bumdes dapat berkembang dengan baik maka kesejahteraan masyarakat dapat terpenuhi, Olehnya itu salah satu jenis usaha yang kami focus adalah usaha Saprodi (Sarana Produksi Pertanian), Usaha saprodi ini untuk Langkah awalnya menyediakan pakan ternak dan obat-obatan ke depannya diharapkan BUMDes mampu memilki pasar sendiri dalam menjual hasil ternak.

Wawancara 2 Darmansyah, SP, MP (KetuaBumdes) umur 26 tahun:

“Untuk pengembangan usaha kedepannya yang kami fokuskan kali ini yaitu usaha saprodi, hal itu kami pikirkan bahwa pada saat ini kami baru bisa menyediakan pakan ternak semoga saja kedepannya jika memiliki kepercayaan dari masyarakat maka kami menginginkan dapat membeli hasil telur dari para peternak. Untuk saat ini rata-rata pengusaha ayam petelur memilki ternak ada yang 1.000 ekor dan ada yang 2.000 ekor dengan jumlah kandang sebanyak 9. Menurut kami sangat potensial misalnya kami dapat 
mengelola dan membeli telur dari peternak dan menjulnya ke pasar, kami yakin kesejahteraan masyarakat akan lebih cepat".

Wawancara Asep Rahmat, umur 51, Pendidikan terakhir S1: “Untuk usaha bumdes yang berpotensi berkembang yaitu usaha pakan ternak yang setiap harinya dibutuhkan peternak ayam petelur.

Kesimpulan dari hasil wawancara mengenai sustainable diatas menunjukkan bahwa baik kepala desa maupun pengurus BUMDes saat ini di Desa Sindang Kasih juga belum maksimal karena dana yang disediakan masih tergolong kecil jadi belum semua masyarakat dapat menikmati serta berharap bahwa usaha BUMDes yang ada sekarang bisa berkelanjutan dan akan lebih bervariasi dalam menyediakan kebutuhan masyarakat dan diharapkan dari banyaknya kebutuhan masyarakat yang diasiapkan maka akan lebih banyak mendapatkan keuntungan yang tentunya akan dapat dinikmati oleh masyarakat desa.

\section{Simpulan}

Dari hasil penelitian yang di lakukan di Desa Sindangkasih Kecamatan Ranomeeto Barat Kabupaten Konawe Selatan. Mengenai Peran Pemerintah Desa dalam Pengeloaan Badan Usaha Milik Desa (BUMDes) maka dapat disimpulkn bahwa pengelolaan Badan Usaha Milik Desa (BUMDes) yang telah dilakukan sampai saat ini cukup baik dari segi peran pemerintah desa. Namun dalam pengelolaannya ini masih ada permsalahan yaitu masih kurangnya dana/anggaran yang diberikan untuk bantuan modal ataupun simpan pinjam dan masih dibatasi untuk warga yang sudah mempunyai usaha serta untuk memproduksi sarana pertanian (sarprodi) masih terbatas. BUMDes belum bisa dinikmati oleh seluruh masyarakat serta masyarakat pun juga masih ada yang belum paham dengan BUMDes itu sendiri. Masih banyaknya masyarakat yang menjual hasil panennya langsung ke pasar atau ke perusahaan lain karena BUMDes belum mampu untuk membeli semua hasil panen dari masyarakat desa.

\section{Ucapan terima kasih}

Alhamdulih penulis haturkan terimakasih kepada LPPM UM Kendari yang telah memberikan hibah untuk penelian ini serta kepada tim penelitian ini yang telah memberikan informasi dan data terkait penelitian ini. Ucapan terimakasih juga disampaikan kepada mahasiswa yang turut membantu dalam memperoleh data penelitian.

\section{Daftar Pustaka}

Agunanto, E. Y. A. F. K. W. D. (2016). Pengembangan Desa Mandiri Melalui Pengelolaan Badan Usaha Milik Desa (BUMDes). 13(1).

Anggaeni, Maria, R. (2016). Peranan Badan Usaha Milik Desa (BUMDES) Pada Kesejahteraan Masyarakat Pedesaan Studi Pada BUMDES di Gunung Kidul Yogyakarta. Modus, 28(2), 155-167. 
Dewi, Amelia, S. K. (2014). Peranan Badan Usaha Milik Desa (BUMDes) sebagai upaya dalam meningkatkan pendapatan asli desa (PADes) serta menumbukan perekonmian desa. Rural and Development, $V$.

Miles Matthew B, H. A. M. (2007). Metode Penelitian. UI Press.

Samsir, A. (2016). 2564-6093-1-PB.pdf. Ad'ministrate, 3(No.2).

Suhu, L. B. D. M. R. S. A. (2020). Analisis Pengelolaan Badan Usaha Milik Desa (BUMDES) Di Desa Geti Baru Kecamatan Bacan Barat Utara Kabupaten Halmahera Selatan.

Sujarweni, W. V. J. M. L. M. I. (2019). Pengelolaan Keuagan Bumdes Sambimulyo di Kawasan Geoheritage "Tebing Breksi" Yogyakarta.

Suprojo, F. (2019). Peran Pemerintahan Desa Dalam Pengembangan Badan Usaha Milik Desa (BUMDes). JISIP, 8(No.4).

Titioka, B. et all. (2020). Pengelolaan Keuangan BUMDES di Kabupaten Kepulaun Aru.

Zulkarnain Ridlwan. (2014). Urgensi Badan Usaha Milik Desa (BUMDES) Dalam Pembangunan Perekonmian Desa. 3(Juli-September). 